\title{
Ontogenesis of Somatomedin and
}

\section{Insulin Receptors in the Human Fetus}

\author{
Vicki R. Sara, Kerstin Hall, Moriharu Misaki, Linda Fryklund, \\ Nils Christensen, and Lennart Wetterberg, Karolinska Institute, \\ Department of Psychiatry, St. Göran's Hospital, S-112 81 Stockholm; \\ Department of Endocrinology Karolinska Hospital, S-104 01 Stockholm; \\ KABIis AB, S-112 87 Stockholm; Department of Obstetrics and Gyncecology, \\ Karolinska Hospital, S-104 01 Stockholm
}

A B S T R A C T This study examines the ontogenesis of somatomedin and insulin receptors in man. Particulate plasma membranes were prepared by ultracentrifugation from various tissues removed from fetuses after abortion and classified as $<17,17-25$, and $>25 \mathrm{~cm}$ in length. The binding of iodinated insulinlike growth factors 1 (IGF-1) and 2 (IGF-2), somatomedin A (SMA), multiplication-stimulating activity (MSA), and insulin was examined at the different ages.

In the liver, cross-reaction studies revealed separate insulin and IGF-2 receptors. The Scatchard plots of insulin binding to liver membranes were curvilinear and showed an increase in the concentration of insulin receptors with advancing age. A single IGF-2 receptor was found on liver and no alteration was observed during development. The brain contained a lower concentration of insulin receptors. A change in the brain receptors for somatomedins occurred during development. Early in gestation, a high concentration of a low-affinity IGF-1 receptor was found. After approximately the 17th wk of gestation a higher affinity IGF1 receptor appeared, which then increased in concentration. Cross-reaction studies also revealed changes in the specificity of these receptors during development. In the youngest fetal group IGF-2 was preferentially bound. Around midgestation a separate IGF1 receptor, indicated by the preferential displacement of iodinated IGF-1 by IGF-1, appeared. In contrast, iodinated IGF-2 bound to a receptor where IGF-1 and IGF-2 were equipotent.

Dr. M. Misaki's present address is Mie University, School of Medicine, Mie 514, Japan.

Received for publication 19 March 1982 and in revised form 23 December 1982.

\section{INTRODUCTION}

The first stage in the action of polypeptide hormones like insulin and the somatomedins is their binding to specific receptor sites on the plasma membrane of their target cells. The existence of such receptors may be used to indicate the targets for hormone action. Several lines of evidence indicate that fetal growth may be regulated by somatomedins and insulin (for review see $1,2)$. Accordingly, somatomedin receptors have been found in the fetal pig (3), rat (4), and sheep (5). In both pig lung (3) and rat brain (4), the concentration of somatomedin receptors is greater in fetal as compared with adult tissue. In man, Rosenfeld et al. (6) reported that the number of somatomedin receptor sites on mononuclear cells was greater in neonates than in adults. Insulin receptors have been reported in fetal pig (3), rat (7, 8), rabbit, and guinea pig (8). In man, insulin binding to mononuclear cells is higher in newborns than in adults (9) and in preterm as compared with term infants (10).

It has been suggested that somatomedins may regulate the early proliferative phase of fetal growth, whereas insulin may influence later hypertrophic growth (11). This study examines the ontogenesis of both somatomedin and insulin receptors in man and relates this to available knowledge concerning the phase of cellular growth in the different organs.

\section{METHODS}

Reagents and hormone preparations. Purified insulinlike growth factor $1($ IGF-1) 1 and $2($ IGF-2) as well as a partially

\footnotetext{
'Abbreviations used in this paper: IGF-1 and IGF-2, insulinlike growth factor 1 and 2; MSA, multiplication-stimulating activity; SMA, somatomedin A.
} 
purified preparation of IGF, specific activity $12.5 \%$ of pure IGF, were kindly provided by $R$. Humbel. Purified somatomedin A (SMA) and a partially purified preparation of SMA, specific activity $10 \%$ of pure SMA, were provided by L. Fryklund. Multiplication-stimulating activity (MSA) was kindly provided by S. P. Nissley and M. M. Rechler. Sephadex G-75 MSA II, containing four closely related polypeptides (12) was used for displacement studies whereas MSA-II-1, prepared from MSA II by preparative-scale disc acrylamide gel electrophoresis (12), was used for iodination. MSA obtained from Collaborative Research Inc., Waltham, MA (MSA-CR) was also used for displacement studies. Porcine insulin $(25 \mathrm{IU} / \mathrm{mg}$ ) and proinsulin were supplied by the Nordic Insulin Laboratories, Niels Steensenvej, 1-DK2820 Gentofte, Denmark. The growth hormone used was Crescormon (4 U/mg), KabiVitrum AB, S-1128 Stockholm. Hormones were labeled by the lactoperoxidase method as described earlier (13). The iodinated IGF-1, IGF-2, MSA, SMA, and insulin were purified on carboxymethylcellulose on a pH gradient in ammonium acetate buffer (0.1 M/liter) (13).

Human fetal tissue. Fetuses were collected with the Ethical Committee's permission. Immediately after legal prostaglandin abortion fetuses were measured and stored in sterile saline at $4^{\circ} \mathrm{C}$. The youngest fetuses examined were $10 \mathrm{~cm}$ in length. Fetuses were classified into three age groups according to length: $(a)<17 \mathrm{~cm}(n=20)$; (b) $17-25 \mathrm{~cm}(n$ $=18) ;(c)>25 \mathrm{~cm}(n=6)$. Livers in the oldest fetal group were further classified into those obtained from fetuses 26 $28 \mathrm{~cm}$ in length $(n=3)$ and those $>28 \mathrm{~cm}$ in length. The corresponding gestational age for these groups was $(a)<17$ $\mathrm{cm} \approx<17 \mathrm{wk} ;(b) 17-25 \mathrm{~cm} \approx 17-22 \mathrm{wk}$; (c) $26-28 \mathrm{~cm}$ $\approx 22-26 \mathrm{wk} ;(d)>28 \mathrm{~cm} \approx<26 \mathrm{wk}$. Within $12 \mathrm{~h}$ after abortion, the whole fetal brain minus cerebellum, liver, kidney, lung, heart, and adrenals were removed, weighed, and stored in $0.25 \mathrm{M}$ sucrose $(1 \mathrm{~g} / \mathrm{ml})$ at $-70^{\circ} \mathrm{C}$ until use. Although the time after fetal death could not be exactly controlled, termination of pregnancy was induced by intramuscular injection of 15-methyl prostaglandin $\mathrm{F}_{2 \alpha}\left(\mathrm{PGF}_{2 \alpha}\right)$ or 16-phenoxy-w-17,18,19,20-tetranor prostaglandin $E_{2}$ methyl sulfonylamide, which resulted in a comparatively short abortion induction time of $\sim 10 \mathrm{~h}$ (14). No significant change in binding was observed when organs were removed within $12 \mathrm{~h}$ after abortion. In the three fetuses examined, the total specific binding of ${ }^{125}$ I-SMA to brain plasma membranes was not affected according to whether the brain tissue was removed immediately (mean \pm SEM: $5.6 \pm 0.2 \%$ ) or $12 \mathrm{~h}$ after abortion $(5.6 \pm 0.1 \%)$. Particulate plasma membranes were prepared from the different organs by ultracentrifugation as described earlier (15). Plasma membranes were pooled according to the various age groups, the protein content determined by the method of Lowry et al. (16) and the membranes diluted in $0.05 \mathrm{M}$ Tris- $\mathrm{HCl}$ buffer ( $\mathrm{pH}$ 7.4) containing $1 \%$ human serum albumin to give a final concentration of $1 \mathrm{mg}$ membrane protein $/ \mathrm{ml}$. Plasma membranes prepared from adrenal glands were pooled from all fetal age groups.

Particulate plasma membrane binding studies. Binding studies were performed in albumin-coated plastic tubes at $4^{\circ} \mathrm{C}$. The incubation mixture had a final volume of $0.3 \mathrm{ml}$ and consisted of $0.1 \mathrm{ml}$ particulate plasma membranes giving a final concentration of $330 \mu \mathrm{g}$ membrane protein $/ \mathrm{ml}, 0.1$ $\mathrm{ml}{ }^{125} \mathrm{I}$-hormone $(0.6 \mathrm{ng} / \mathrm{ml}$ final concentration), and $0.1 \mathrm{ml}$ $0.05 \mathrm{M}$ Tris-HCl buffer (pH 7.4) containing $1 \%$ human serum albumin (Tris-albumin buffer) or unlabeled hormone in Trisalbumin buffer. Incubation was at $+4^{\circ} \mathrm{C}$ for $20 \mathrm{~h}$ and was terminated by the addition of $0.7 \mathrm{ml}$ ice-cold Tris-albumin buffer. Samples were mixed and centrifuged at $10,000 \mathrm{~g}$ for
$30 \mathrm{~min}$ at $+4^{\circ} \mathrm{C}$. Plasma membranes were again washed with $1 \mathrm{ml}$ Tris-albumin buffer, dried and then counted in a gamma counter (Packard Instrument Co., Downers Grove, IL) for $10 \mathrm{~min}$ for the determination of membrane-bound radioactivity. Nonspecific binding was defined as the radioactivity that remained bound in the presence of $1 \mu \mathrm{g}$ hormone $/ \mathrm{ml}$. Where sufficient hormone was not available, 3 $\mu \mathrm{g} / \mathrm{ml}$ of partially purified IGF or SMA was used. Values represent the mean of triplicate determinations. Due to the changing cell composition of the tissues through development, enzyme membrane markers could not be applied and the membrane protein content was chosen as the common reference.

Because of the limited membrane, studies of binding conditions were performed only with brain and liver plasma membranes. At all ages, binding of all ligands had achieved a steady state after $20 \mathrm{~h}$ incubation at $+4^{\circ} \mathrm{C}$. Similarly, ligand degradation, estimated by reincubation of the supernatant with new membrane, had reached a steady state at this time. The percentage of degraded unbound ligand was always $<4 \%$. The binding of iodinated somatomedins was stable over a wide pH range (6-9) whilst insulin binding was stable over a narrower range (7-8). With all ligands binding increased similarly with increasing concentrations of membrane protein. However, to reach maximal binding it was necessary to use at least $1 \mathrm{mg}$ membrane protein $/ \mathrm{ml}$. Since this amount was not available for all tissues, a concentration of $330 \mu \mathrm{g}$ membrane protein $/ \mathrm{ml}$ was chosen as the reference for comparison.

The number and affinity of receptor sites were calculated by Scatchard analysis (17) using the MLAB program provided by National Institues of Health in a Dec 10 computer system. The results were drawn by computer using the MLAB program.

\section{RESULTS}

In a screening procedure all fetal organs examined, i.e., liver, brain, heart, kidney, lung, and adrenals were found to bind iodinated somatomedins and insulin.

Because of the limited availability of hormones in

TABLE

Total Specific Binding of ${ }^{125}$ I-Labeled IGF-1, IGF-2, SMA, MSA, and Insulin to Plasma Membranes Prepared from Human Fetal Liver and Brain at Different Ages

\begin{tabular}{ccccccc}
\hline & & \multicolumn{5}{c}{ Percent total specific binding } \\
\cline { 3 - 7 } Organ & $\begin{array}{c}\text { Fetal } \\
\text { length }\end{array}$ & IGF-1 & IGF-2 & SMA & MSA & Insulin \\
\hline \multirow{4}{*}{ Liver } & $c m$ & & & & & \\
& $<17$ & 2.8 & 9.8 & 2.3 & 5.1 & 9.8 \\
& $17-25$ & 3.2 & 7.7 & 3.0 & 5.6 & 7.1 \\
& $26-28$ & 3.6 & 11.6 & 2.6 & 4.7 & 12.1 \\
& $>28$ & 3.2 & 9.5 & 2.6 & 4.0 & 14.6 \\
Brain & $<17$ & 13.9 & 5.7 & 5.8 & 5.7 & 2.0 \\
& $17-25$ & 13.1 & 5.5 & 5.4 & 3.4 & 2.5 \\
& $>25$ & 21.0 & 14.0 & 5.2 & 5.5 & 3.8 \\
\hline
\end{tabular}

Total specific binding is expressed as the percentage of added radioactivity bound in the presence of $3 \mu \mathrm{g} / \mathrm{ml} \mathrm{IGF} \mathrm{(12.5 \% ),} \mathrm{SMA}$ (10\%), MSA-CR, and insulin. 
the somatomedin family, specific binding was only examined in the liver and brain. Specific binding, given in Table I, was determined in the presence of $3 \mu \mathrm{g} / \mathrm{ml}$ of partially purified IGF (12.5\%), SMA (10\%), and purified MSA-CR, and insulin. This amount was chosen since in both brain and liver no further decrease in binding was observed with increasing hormone concentration. In spite of this, both IGF-2 and MSA showed a high unspecific binding corresponding to $3-6 \%$ of the added radioactivity.

In liver membranes examined at four stages throughout fetal development the highest specific binding is found with ${ }^{125}$ I-labeled insulin and IGF-2 even though the latter displays high nonspecific binding. ${ }^{125}$ I-Labeled IGF-1, MSA, and SMA show far less specific binding to fetal liver membranes than IGF-2 (Table I). Fig. 1 shows the displacement curves of bound ${ }^{125}$ I-insulin and ${ }^{125}$ I-IGF-2 by increasing concentrations of insulin, IGF-1, IGF-2, and impure IGF. Insulin did not cross-react in the IGF-2 receptor. In contrast, impure IGF competed with insulin for its receptor and was $\sim 1,000$ times less potent than insulin in displacing ${ }^{125} \mathrm{I}$-insulin from the liver membrane. Competitive binding by other somatomedins was examined in the 17-25-cm group (data not shown). The relative potencies compared with insulin in displacing ${ }^{125}$ I-insulin were IGF-2-1:100; IGF-1-1:300; MSACR-1:300. Partially purified SMA (10\%) was nonreactive at concentrations up to $3 \mu \mathrm{g} / \mathrm{ml}$. The relative potencies compared with IGF-2 in displacing ${ }^{125} \mathrm{I}-\mathrm{IGF}$ 2 were IGF-1-1:10; MSA-CR-1:10; SMA (10\%)$1: 100$. Thus, separate insulin and IGF-2 receptors are present on human fetal liver plasma membranes.

The Scatchard plots of insulin binding to liver mem-

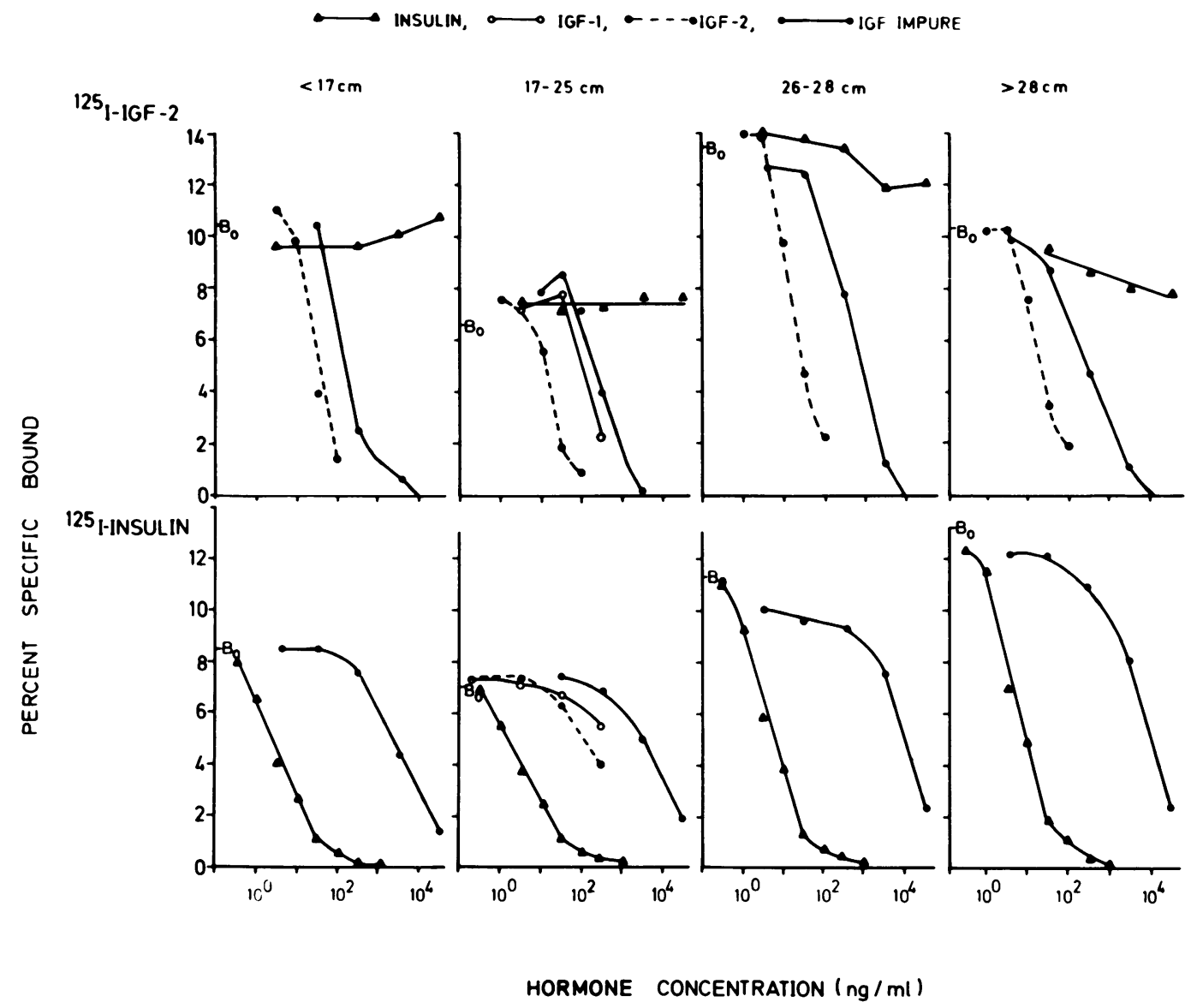

Figure 1 Specific binding of ${ }^{125} \mathrm{I}-\mathrm{IGF}-2$ (above) and ${ }^{125} \mathrm{I}$-insulin (below) to human fetal liver plasma membranes $(330 \mu \mathrm{g}$ membrane protein $/ \mathrm{ml}$ ). Livers were removed from fetuses classified into four ages according to length: $<17,17-25,26-28,>28 \mathrm{~cm}$. Total specific binding at each age is given as Bo. Displacement of ${ }^{125} \mathrm{I}-\mathrm{IGF}-2$ and ${ }^{125} \mathrm{I}$-insulin by different concentrations of unlabeled insulin $(\Delta-\Delta)$, IGF-1 $(\mathrm{O}-0)$, IGF-2 $(\bullet---0)$ and IGF-12.5\% $(-\bullet)$ is shown. 


\section{HUMAN FETAL LIVER (330 $\mathrm{\mu g}$ memorane protein $/ \mathrm{m})$}

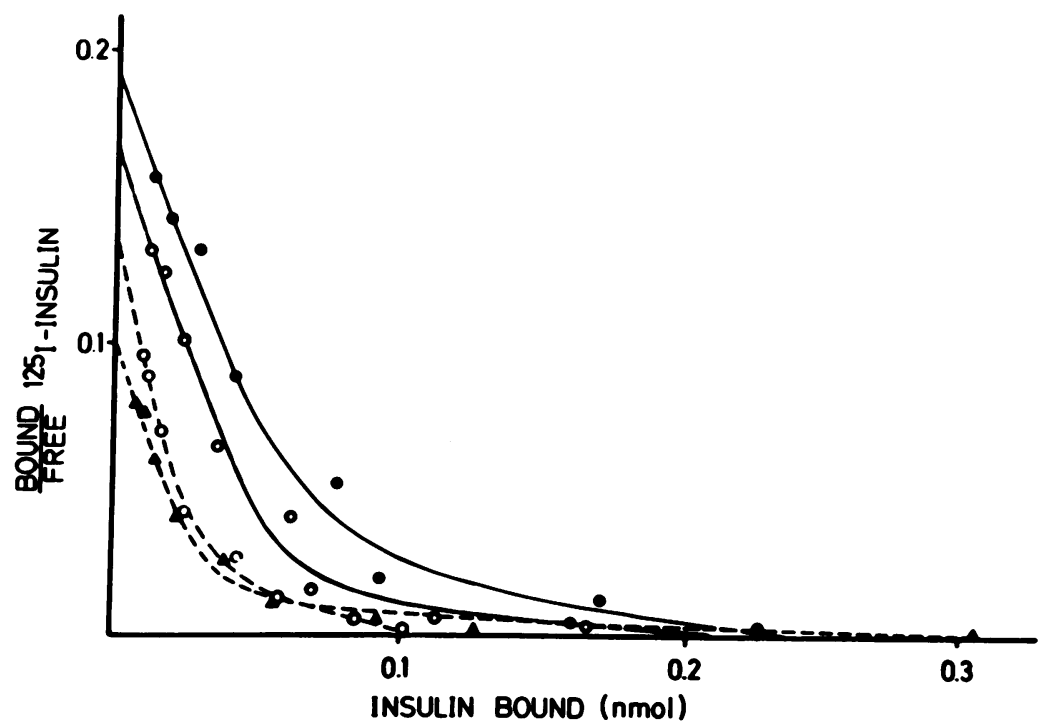

FIGURE 2 Scatchard plots of insulin binding to human fetal liver plasma membrane (330 $\mu \mathrm{g}$ membrane protein $/ \mathrm{ml}$ ) at different developmental stages classified according to fetal length:

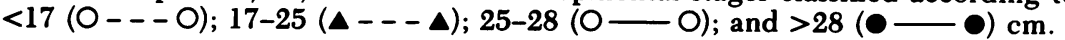

branes at different fetal ages is given in Fig. 2. A curvilinear plot is observed at each fetal stage indicating the presence of at least two binding sites or negative co-operativity. Since resolution of these alternatives is beyond the scope of this paper, the presence of two receptor sites was assumed and the calculated affinity and concentration of high- and low-affinity insulin binding sites is given in Table II. The increase in specific binding at fetal size $>25 \mathrm{~cm}$ is mainly attributed to the increase in the concentration of binding sites with gestational age. A change in the characteristics of the insulin receptor is suggested in the youngest fetal group by the alteration in affinity of both the high- and low-affinity insulin binding sites.
In contrast to insulin, Scatchard analysis revealed linear plots for IGF-2 binding to liver membranes. The affinity and concentration of IGF-2 binding sites on the liver is given in Table II. Neither the affinity nor concentration of IGF-2 binding sites on the liver membranes appeared to alter during development.

Whereas IGF-2 and insulin were preferentially bound by liver membranes and little binding of IGF1 was observed, the highest specific binding to brain membranes occurred with IGF-1 followed by IGF-2. In comparison with the liver, specific insulin binding to brain membrane was much lower. Displacement of ${ }^{125}$ I-IGF-1, ${ }^{125}$ I-IGF-2, and ${ }^{125}$ I-insulin with IGF-1, IGF-2, and insulin from brain plasma membranes at

TABLE II

Calculated Affinity Constant and Concentration of Insulin and IGF-2 Binding Sites on Human Fetal Liver Plasma Membrane

\begin{tabular}{|c|c|c|c|c|c|c|}
\hline \multirow{3}{*}{$\begin{array}{c}\text { Fetal } \\
\text { length }\end{array}$} & \multicolumn{4}{|c|}{ Insulin binding site } & & \\
\hline & \multicolumn{2}{|c|}{ High affinity } & \multicolumn{2}{|c|}{ Low affinity } & \multicolumn{2}{|c|}{ IGF-2 binding site } \\
\hline & Affinity constant & Concentration & Affinity constant & Concentration & Affinity constant & Concentration \\
\hline $\mathrm{cm}$ & $\mathrm{mol}^{-1}$ & $\mathrm{~mol} / \mathrm{g}$ & $\mathrm{mol}^{-1}$ & $\mathrm{~mol} / \mathrm{g}$ & $\mathrm{mol}^{-1}$ & $\mathrm{~mol} / \mathrm{g}$ \\
\hline$<17$ & $4.62 \times 10^{9}$ & $0.08 \times 10^{-9}$ & $1.56 \times 10^{8}$ & $0.28 \times 10^{-9}$ & $0.87 \times 10^{9}$ & $0.64 \times 10^{-9}$ \\
\hline $17-25$ & $2.87 \times 10^{9}$ & $0.10 \times 10^{-9}$ & $0.22 \times 10^{8}$ & $0.97 \times 10^{-9}$ & $0.64 \times 10^{9}$ & $0.53 \times 10^{-9}$ \\
\hline $26-28$ & $2.62 \times 10^{9}$ & $0.18 \times 10^{-9}$ & $0.42 \times 10^{8}$ & $0.54 \times 10^{-9}$ & $0.85 \times 10^{9}$ & $0.83 \times 10^{-9}$ \\
\hline$>28$ & $2.62 \times 10^{9}$ & $0.20 \times 10^{-9}$ & $0.79 \times 10^{8}$ & $0.58 \times 10^{-9}$ & $0.66 \times 10^{9}$ & $0.70 \times 10^{-9}$ \\
\hline
\end{tabular}


three age groups is given in Fig. 3. Similar to the liver, both IGF-1 and IGF-2 competed with insulin for its binding site on brain membrane. The Scatchard plots of insulin binding to fetal brain plasma membrane were also curvilinear. This could indicate the presence of at least two receptors or negative co-operativity. The affinity constants and concentration of insulin receptors on fetal brain plasma membrane is given in Table III. A change in the affinity of the high-affinity binding site in the 17-25 cm fetal group is observed. In comparison with the liver, the brain contains a significantly lower concentration of high-affinity insulin binding sites (Tables II and III).

An interesting change in the pattern of cross-reaction when IGF-1 is used as label is observed on the brain plasma membrane during development (Fig. 3). In the youngest fetal group ( $<17 \mathrm{~cm}$ in length), ${ }^{125} \mathrm{I}$ -
IGF-1 is preferentially displaced by IGF-2 whereas in the $17-25-\mathrm{cm}$ fetal group, IGF-1 and IGF-2 are equipotent, and in the oldest fetal group ( $>25 \mathrm{~cm})$, IGF1 is more potent than IGF-2. This change in specificity confirmed by repeat experiment, cannot be attributed to the ligand, since when tested on human term placenta membrane, IGF-1 was threefold more potent than IGF-2 in displacing ${ }^{125} \mathrm{I}-\mathrm{IGF}-1$. Moreover in the $>25-\mathrm{cm}$ fetal group, IGF-1 again preferentially displaces ${ }^{125}$ I-IGF-1 from the brain membrane. These results suggest alterations in the characteristics of the IGF-1 receptor during development, which is also apparent in the Scatchard plots for IGF-1 binding to human fetal brain plasma membrane (Fig. 4). A linear Scatchard plot is observed at all fetal ages indicating the presence of a single receptor. The calculated affinity and concentration of binding sites is given in

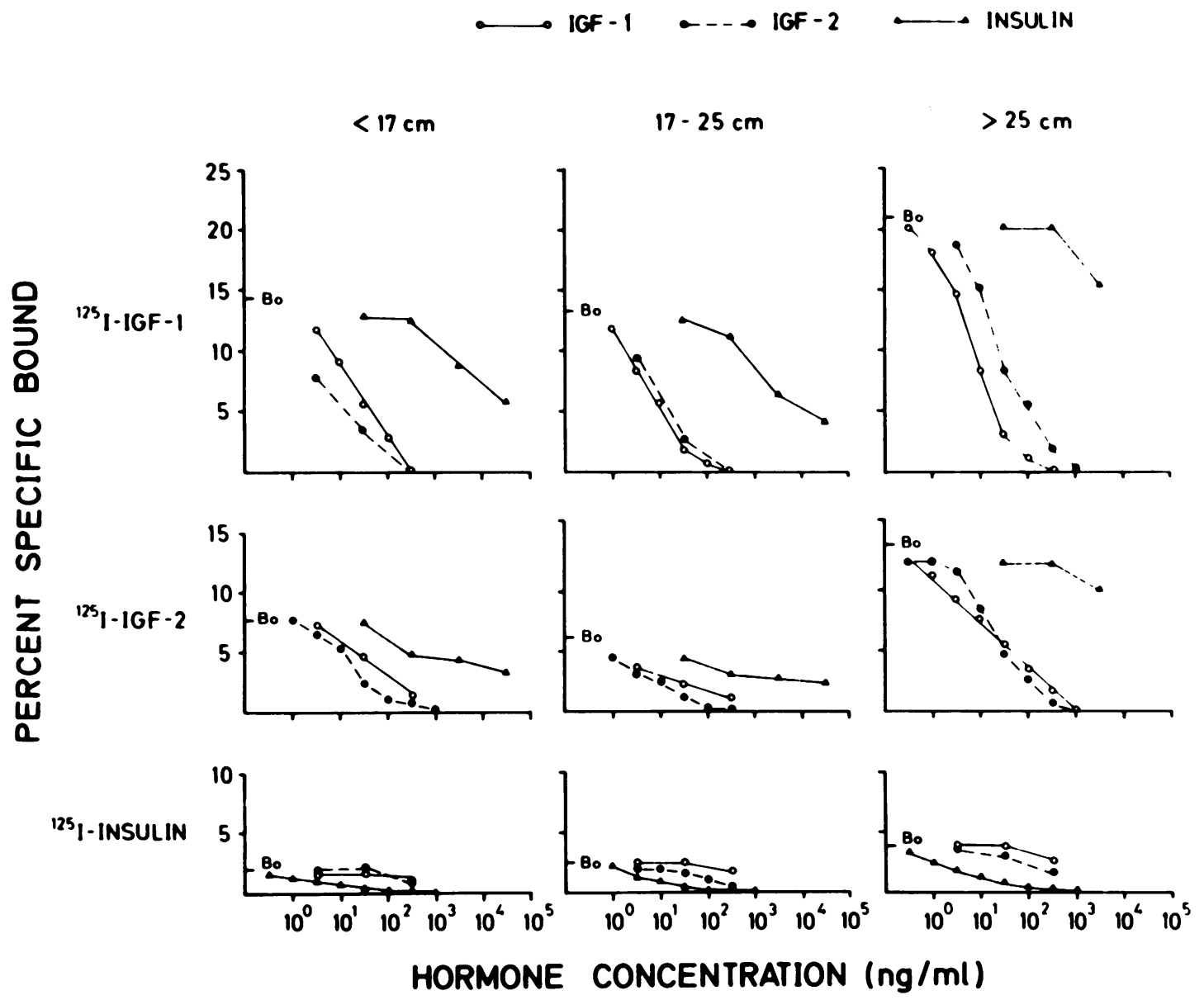

Figure 3 Specific binding of ${ }^{125}$ I-IGF-1 (upper), ${ }^{125}$ I-IGF-2 (middle), and ${ }^{125}$ I-insulin (below) to human fetal brain plasma membranes $(330 \mu \mathrm{g}$ membrane protein $/ \mathrm{ml})$ at different developmental stages classified according to fetal length: $<17$ (left), 17-25 (middle), and $>25$ (right) $\mathrm{cm}$. Total specific binding is given as Bo. Displacement by different concentrations of unlabeled IGF-1 $(\mathrm{O}-\mathrm{O})$, IGF-2 $(\bullet---\bullet)$, and insulin $(\Delta-\Delta)$ is shown. 
TABLE III

Calculated Affinity Constant and Concentration of Insulin, IGF-1, and IGF-2 Binding Sites on Human Fetal Brain Plasma Membrane

\begin{tabular}{|c|c|c|c|c|c|c|c|c|}
\hline \multirow{3}{*}{$\begin{array}{c}\text { Fetal } \\
\text { length }\end{array}$} & \multicolumn{4}{|c|}{ Insulin binding site } & & & & \\
\hline & \multicolumn{2}{|c|}{ High affinity } & \multicolumn{2}{|c|}{ Low affinity } & \multicolumn{2}{|c|}{ IGF-I binding site } & \multicolumn{2}{|c|}{ IGF-2 binding site } \\
\hline & Affinity constant & Concentration & Affinity constant & Concentration & Affinity constant & Concentration & Affinity constant & Concentration \\
\hline $\mathrm{cm}$ & $\mathrm{mol}^{-1}$ & $\mathrm{~mol} / \mathrm{g}$ & $\mathrm{mol}^{-1}$ & $\mathrm{~mol} / \mathrm{g}$ & $\mathrm{mol}^{-1}$ & $\mathrm{~mol} / \mathrm{g}$ & $\mathrm{mol}^{-1}$ & $\mathrm{~mol} / \mathrm{g}$ \\
\hline$<17$ & $3.30 \times 10^{9}$ & $0.02 \times 10^{-9}$ & $5.83 \times 10^{6}$ & $3.92 \times 10^{-9}$ & $0.45 \times 10^{9}$ & $1.19 \times 10^{-9}$ & $0.72 \times 10^{9}$ & $0.43 \times 10^{-9}$ \\
\hline $17-25$ & $1.49 \times 10^{9}$ & $0.05 \times 10^{-9}$ & $4.77 \times 10^{6}$ & $3.80 \times 10^{-9}$ & $1.65 \times 10^{9}$ & $0.32 \times 10^{-9}$ & $1.41 \times 10^{9}$ & $0.16 \times 10^{-9}$ \\
\hline$>25$ & $3.71 \times 10^{9}$ & $0.03 \times 10^{-9}$ & $6.90 \times 10^{6}$ & $3.25 \times 10^{-9}$ & $2.08 \times 10^{9}$ & $0.45 \times 10^{-9}$ & $0.65 \times 10^{9}$ & $0.84 \times 10^{-9}$ \\
\hline
\end{tabular}

Table III. The increase in specific binding with increasing age is mainly due to an increase in affinity constant. In the youngest fetal group $(<17 \mathrm{~cm})$ a higher concentration of a lower affinity IGF-1 binding site is observed. During maturation, however, the affinity changes and a binding site with higher affinity is observed on the brain plasma membrane of fetuses 17$25 \mathrm{~cm}$ in length. With advancing age $(>25 \mathrm{~cm})$, a slight increase in the concentration of this receptor is found.
In the youngest age group, IGF-2 was more potent than IGF-1 in displacing both bound ${ }^{125}$ I-IGF-1 and bound ${ }^{125}$ I-IGF-2 (Fig. 3) suggesting the presence of an IGF-2-like receptor. The calculated high-affinity constant for IGF-2 was also somewhat higher than that for IGF-1 (Fig. 5, Table III). In this context it was confusing to find that the specific binding was lower for the IGF-2 than IGF-1. The only explanation we can offer is that the iodination of IGF-2 has produced

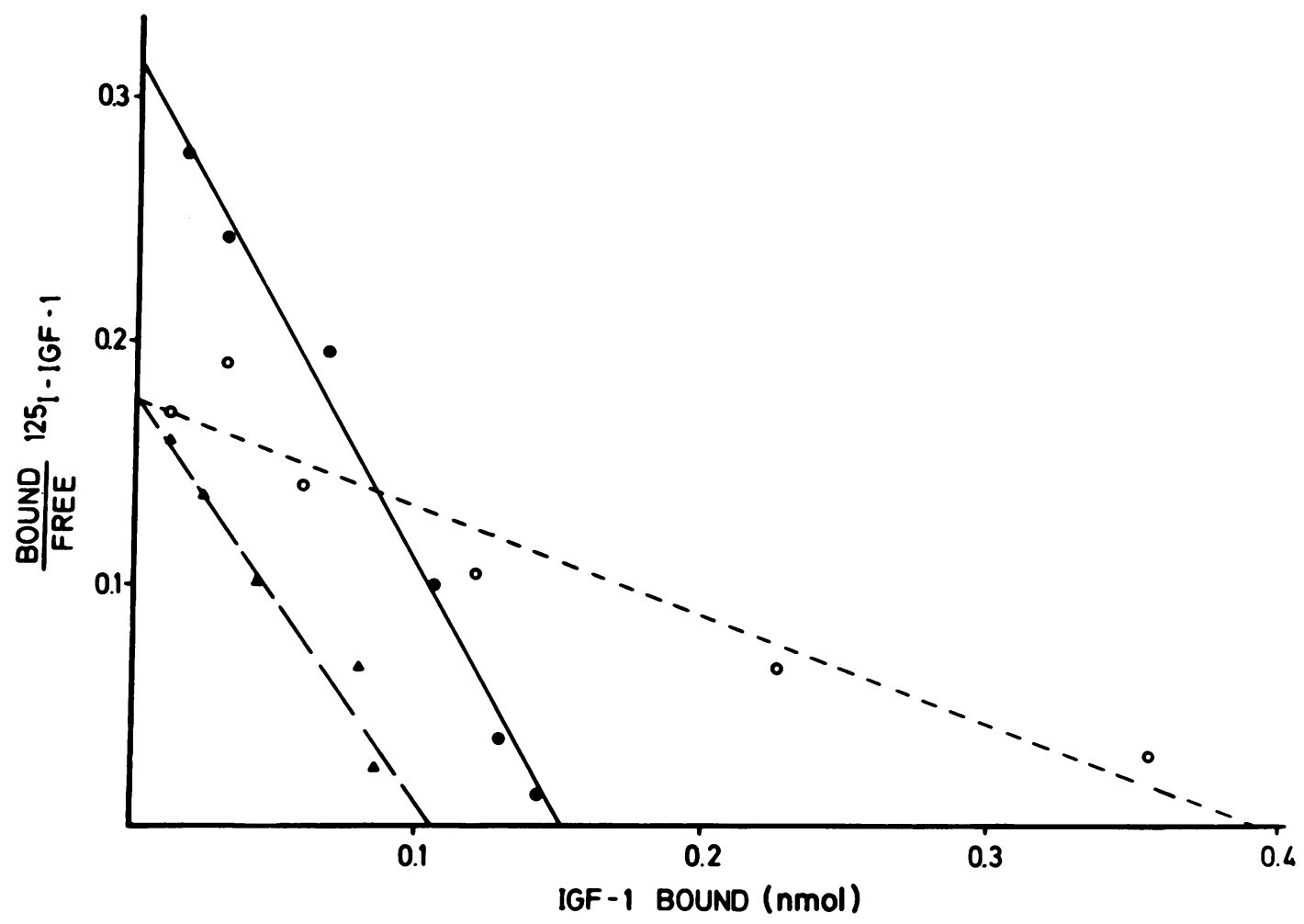

Figure 4 Scatchard plots of IGF-1 binding to human fetal brain plasma membrane (330 $\mu \mathrm{g}$ membrane protein $/ \mathrm{ml}$ ) at different developmental stages classified according to fetal length: $<17(0--0), 17-25(\Delta---\Delta),>25(--0) \mathrm{cm}$. 


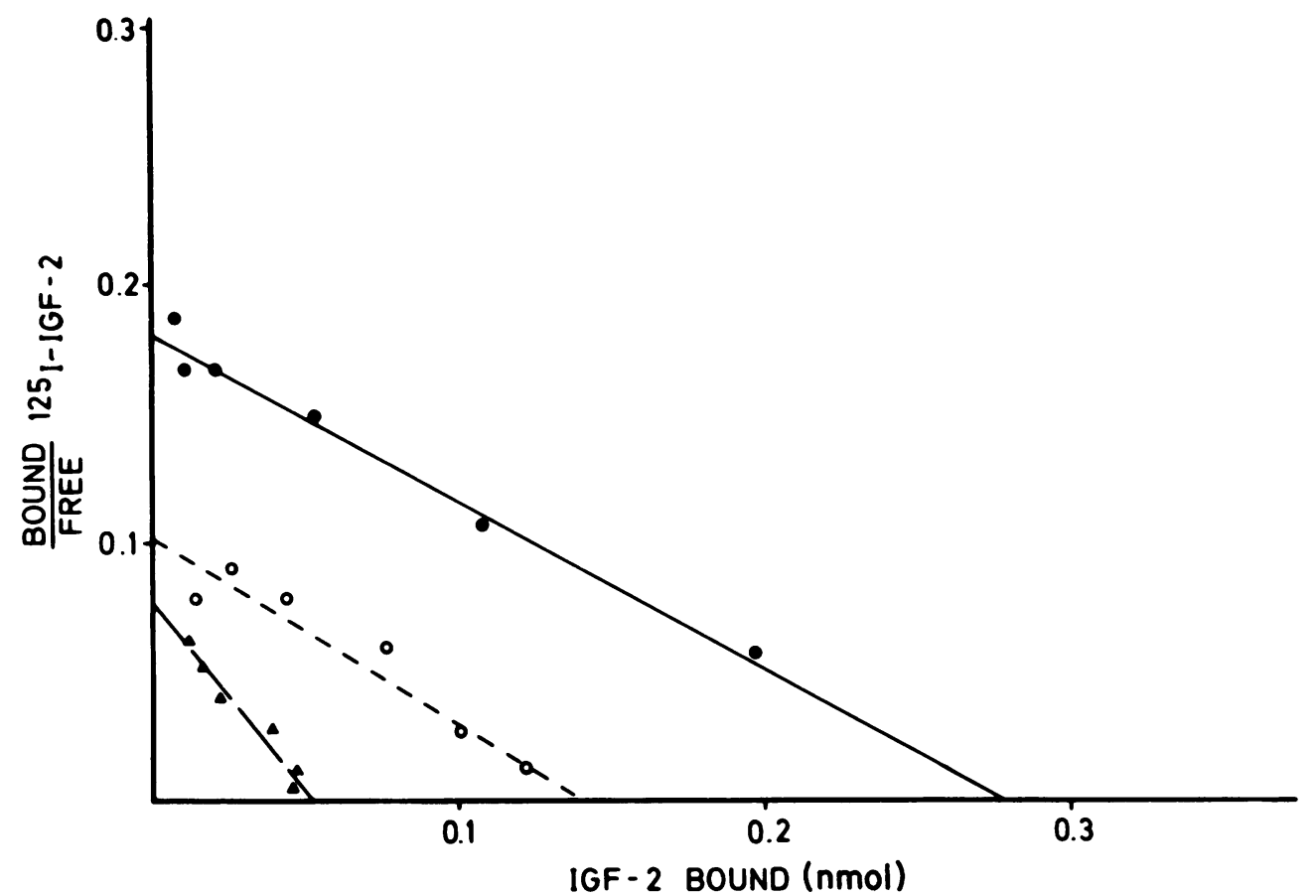

FigURE 5 Scatchard plots of IGF-2 binding to human fetal brain plasma membrane (330 $\mu \mathrm{g}$ membrane protein $/ \mathrm{ml}$ ) at different developmental stages classified according to fetal length: $<17(\mathrm{O}---\mathrm{O}), 17-25(\Delta---\Delta),>25(\bullet-\bullet) \mathrm{cm}$.

subtle alterations in its binding region that would invalidate the Scatchard analysis of the IGF-2 binding data. Such effects have not been observed in binding studies using placenta or postnatal tissues, suggesting that the binding region of IGF-2 is different for the early fetal receptor. With increasing age, IGF-2 and IGF-1 become more equipotent in displacing IGF-2 from its receptor and, in the intermediate age group $(17-25 \mathrm{~cm})$, the calculated affinity constant for IGF2 was identical with that for IGF-1. This finding together with the equipotency of IGF-1 and IGF-2 in displacing the respective IGF from its receptor suggested a common receptor at this age. However insulin, which cross-reacted in both binding sites, showed different displacement curves, suggesting that there is more than one common receptor. With further increases in age, IGF-1 and IGF-2 are almost equipotent but the displacement curves are not superimposable.

Since the cross-reaction between IGF-1 and IGF-2 suggested the presence of further somatomedin receptors, specificity was explored using brain plasma membranes prepared from the 17-25-cm fetal group. Fig. 6 shows the cross-reaction of IGF-1, IGF-2, SMA, MSA and insulin when each hormone is used as the ligand. The highest total specific binding was found with ${ }^{125} \mathrm{I}$ IGF-1 (13.3\%) followed by ${ }^{125}$ I-IGF-2 (5.9\%), ${ }^{125}$ I-SMA $(5.7 \%),{ }^{125} \mathrm{I}-\mathrm{MSA}(3.4 \%)$, and ${ }^{125}$ I-insulin (2.5\%). At this age, regardless of which ${ }^{125}$ I-somatomedin is used as the ligand, it is best displaced by IGF-1 and IGF-2. When ${ }^{125}$ I-IGF-1, ${ }^{125}$ I-SMA, or ${ }^{125}$ I-MSA were used the pattern of cross-reaction was identical. IGF-1 and IGF2 were equipotent. SMA and MSA were $\sim 10$-fold less potent than IGF-1 and IGF-2. Since the partially purified SMA (10\%) was equipotent with SMA (data not shown), this preparation must contain hormones additional to SMA that cross-react in the brain receptor. Insulin and proinsulin (data not shown) were 100 and 1,000 times respectively less potent than IGF-1. Other hormones, such as growth hormone and prolactin, and growth factors such as nerve growth factor, fibroblast growth factor, and epidermal growth factor did not cross-react in the human fetal brain somatomedin receptor. With IGF-2 as the labeled hormone the pattern of cross-reaction is quite different. None of the tested hormones showed displacement curves parallel with that for IGF-2. The order of potency was discrepant from other somatomedins and insulin only caused a $50 \%$ inhibition of the bound ${ }^{125}$ I-IGF-2.

When ${ }^{125}$ I-insulin was used as the ligand, it was preferentially displaced by insulin. Proinsulin (data not shown) and IGF-2 also cross-react in the brain insulin receptor and are $\sim 10$-fold less potent than insulin in displacing ${ }^{125}$ I-insulin from the membrane. IGF-1 and MSA were 100-fold less potent than insulin. The cross- 


\section{HUMAN FETAL BRAIN $(17-25 \mathrm{~cm})$}
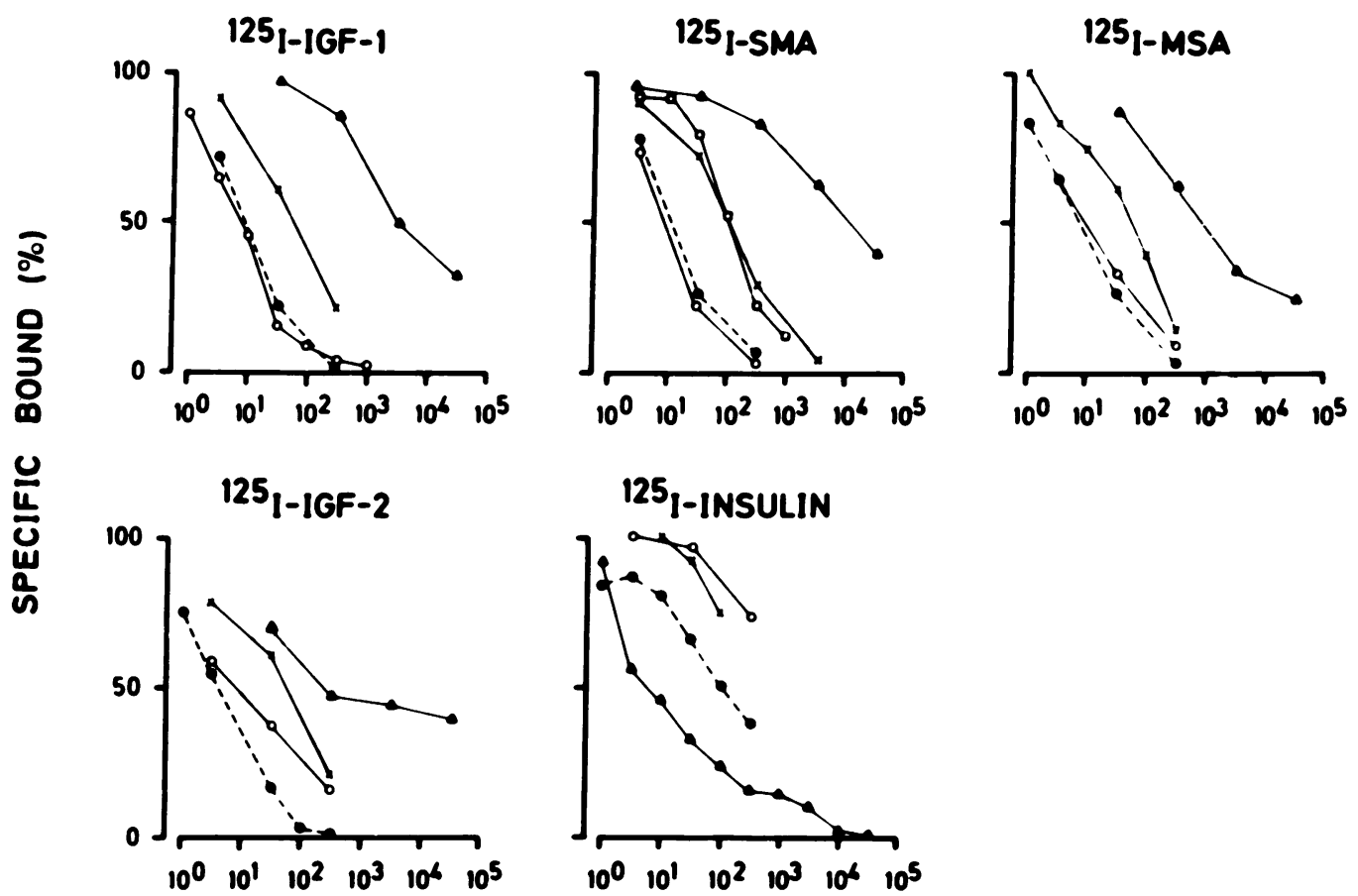

HORMONE CONCENTRATION $(\mathrm{ng} / \mathrm{ml})$

FigURE 6 Displacement of ${ }^{125} \mathrm{I}-\mathrm{IGF}-\mathrm{I},{ }^{125} \mathrm{I}-\mathrm{SMA},{ }^{125} \mathrm{I}-\mathrm{MSA},{ }^{125} \mathrm{I}-\mathrm{IGF}-2$, and ${ }^{125} \mathrm{I}$-insulin from brain plasma membrane $(330 \mu \mathrm{g}$ membrane protein $/ \mathrm{ml})$ prepared from human fetuses $(17-25$ $\mathrm{cm}$ length) by different concentrations of unlabeled IGF-1 (O- $-O)$, IGF-2 (- - - ), SMA $(\square-\square)$, MSA $(\times-\times)$, and insulin $(\boldsymbol{\Lambda}-\mathbf{\Delta})$.

reaction studies indicate the existence of separate somatomedin and insulin receptors on human fetal brain plasma membrane.

\section{DISCUSSION}

The present results demonstrate the presence of somatomedin and insulin receptors in the human fetus. Receptors were present before the end of the first trimester of gestation, suggesting that the human fetus is, already early in gestation, a target for somatomedin and insulin action. The influence of intramuscular prostaglandin administration on the fetus is unknown. However, using this route of administration it is unlikely that prostaglandins are present in sufficient quantities to significantly influence fetal receptors, since only small amounts were present after intraamniotic administration $(18,19)$.

Cross-reaction studies using liver and brain plasma membranes showed separate receptors for somatomedin and insulin. In the brain, somatomedin and insulin at high concentrations, could compete with each other for binding to their respective receptors. In the liver however, insulin did not cross-react in the IGF2 receptor although high concentrations of IGF-2 displaced insulin from its receptor. These findings in the human fetus are similar to the cross-reaction pattern for the IGF-2 receptor on adult rat liver plasma membranes reported by Rechler et al. (20).

In both liver and brain, the receptors for somatomedins appeared to preferentially recognize either IGF-1 or IGF-2. In a recent study, Marquardt et al. (21) have sequenced one of the MSA species and shown close homology to IGF-2. This MSA is most likely MSA III-2 $(12,21)$. The present studies used MSA II and MSA II-1, which show less potent cross-reaction in various receptors than MSA III-2 $(22,23)$. Thus, the relative potencies found in the present studies may not 
be valid for other MSA species. The pattern of recognition varied between these organs. IGF-1 was preferentially bound by brain whereas IGF-2 was preferentially bound by liver. The specificity of the receptors for somatomedins also seemed to vary with gestational age. In the brain during the earliest developmental stage, IGF-2 was preferentially bound. With increasing maturation however, a separate IGF1 receptor emerged.

A dramatic change in the receptors for somatomedins occur in the brain during development. Before the end of the first trimester of gestation, a lower-affinity IGF-1 receptor is present in high concentration on the brain membranes. The lower-affinity receptor disappears around the 17th wk of gestation when a higher-affinity IGF-1 receptor appears. At $\sim 25 \mathrm{wk}$ of gestational age, the affinity constant and pattern of cross-reaction of the IGF-1 receptor is almost identical to that found in the adult human brain (24). Further characterization of this early fetal brain receptor presents an intriguing problem. Not only does the affinity change but the pattern of cross-reaction is altered after $\sim 17$ wk of gestation age. Regardless of the iodinated somatomedin used, the early receptor preferentially recognizes IGF-2. Around midgestation, however, a separate IGF-1 receptor on the brain begins to appear whereas iodinated IGF-2 binds to a receptor where IGF-1 and IGF-2 are equipotent. The explanation for this is at present unclear. IGF-2 may be binding to both IGF-1 and IGF-2 receptors whose physical separateness has been indicated by affinity cross-linking studies (25). Alternatively, IGF-2 may be binding to a receptor for another related but as yet unidentified polypeptide.

A change in all brain receptors was observed at $\sim 17$ wk of gestation. Not only did the affinity of the IGF-1 receptor show a fourfold increase but a fall in the affinity of the high-affinity insulin receptor was observed. Unfortunately, the suspected alteration in IGF-2 by iodination invalidates the Scatchard analysis of IGF-2 binding to brain membranes in the youngest fetal group. Due to limited material, it was not possible to examine either the specific brain areas or cellular types containing the somatomedin and insulin receptors. However, the brain region used in this study corresponds to that studied by Dobbing and Sands (26). These authors showed a biphasic pattern of cellular proliferation in human fetal forebrain (whole brain minus cerebellum and stem) that coincides with the change in brain receptor characteristics reported in this study. Dobbing and Sands (26) report an early rapid period of cell proliferation between $\sim 12$ and $18 \mathrm{wk}$ of gestation, followed by a more gradual increase in cell number until after birth. The early period is thought to be predominantly due to the for- mation of neuroblasts, which thereafter differentiate into mature neurones. Glial cell formation is believed to predominate in the late proliferative phase. The presence of the lower-affinity IGF-1 receptor during the rapid proliferative phase suggests that it may be present on the stem cells or immature neurones. This would be in accordance with the earlier hypothesis of Sara and Hall (1) and Sara et al. (27) that there exists a specific fetal form of somatomedin which in man is termed human embryonic somatomedin, and which is recognized by a corresponding fetal or immature somatomedin receptor. The appearance of the higher affinity IGF-1 receptor corresponds to the maturation period of neuronal growth and may be present on mature neurones. However, glial cell origin cannot be disregarded since such cells are being rapidly formed in the brain during the later stages of gestation. Resolution of this problem must await more specialized studies of receptor localization.

In contrast to the brain, the IGF-2 receptor on the liver appears to remain unaltered throughout gestation. The affinity of the liver insulin receptor, however, changes after the fetus has attained $17 \mathrm{~cm}$ in length. Thereafter the affinity remains constant and there is an increase in the concentration of insulin receptors. Bernard et al. (28) reported that the transition from fetal to adult forms of thymidine kinase in the human liver occurred at this fetal age. Both these findings indicate a change in liver cell characteristics around the 17th wk of gestational age.

Apart from brain growth, which has been well documented, there is little data available concerning the different periods of cellular growth in the other human fetal organs. Widdowson et al. (9) have examined DNA and protein accumulation in kidneys, heart, liver, and muscle. In all organs cell proliferation occurred rapidly until $\sim 25$ wk of gestation when the rate of cell formation began to slow and there was growth in terms of cell size. Early in gestation, somatomedin binding was observed in both fetal organs whereas insulin binding tended to increase with increasing maturation. These data suggest that whereas the somatomedins are active from early development, insulin may play a regulatory role later in development. Such a conclusion is in accordance with Hill et al. (30) observations of the growth of fetuses with pancreatic agenesis, where fetal growth appears to have ceased at approximately week 28 of gestation. Similarly, the increased growth of fetuses of diabetic mothers is primarily observed after the same gestational age (31). Thus, the present findings support the concept that in man, the somatomedins are the primary regulators of the early period of proliferative growth whereas insulin plays a later regulatory role on maturation and hypertrophic growth.

The profound growth retardation observed in Lep- 
rechaunism is accompanied not only by insulin resistance but in some instances by a severe reduction in the affinity of the IGF-1 receptor (32) and in others by a probable defect in the somatomedins postreceptor mechanism $(33,34)$. The contribution that defects in somatomedin receptors make to other causes of intrauterine growth retardation remains to be explored.

\section{ACKNOWLEDGMENTS}

The kind provision of IGF-1 and IGF-2 by René Humbel and of MSA by S. Peter Nissley and Mattew Rechler is gratefully acknowledged. The technical assistance of Barbro Sjögren, Eva Hall and Irmgard Kajanus, and the help of the nursing staff at the World Health Organization unit, Karolinska Hospital, is gratefully acknowledged.

This study was supported by Riksbankens Jubileumsfond, the Swedish Medical Research Council (4224 and 5669), The "Expressen" Prenatal Research Fund and Sävstaholmsföreningen.

\section{REFERENCES}

1. Sara, V. R., and K. Hall. 1980. Somatomedins and the fetus. Clin. Obstet. Gynecol. 23: 765-778.

2. Persson, B. 1981. Insulin as a growth factor in the fetus. In The Biology of Normal Human Growth. M. Ritzén, A. Aperia, K. Hall, A. Larsson, A. Zetterberg, and R. Zetterström, editors. Raven Press, New York. 213-221.

3. D'Ercole, A. J., D. B. Foushee, and L. E. Underwood 1976. Somatomedin-C receptor ontogeny and levels in porcine fetal and human cord serum. J. Clin. Endocrinol. Metab. 43: 1069.

4. Sara, V. R., K. Hall, A. Ottosson-Seeberger, and L. Wetterberg. 1980. The role of the somatomedins in fetal growth. In Endocrinology 80. I. A. Cumming, J. W. Funder, and F. A. O. Mendelson, editors. Canberra A.A.S. $453-456$.

5. Owens, P. C., M. W. Brinsmead, M. J. Waters, and G. D. Thorburn. 1980. Ontogenetic changes in multiplication-stimulating activity binding to tissues and serum somatomedin-like receptor activity in the ovine fetus. Biochem. Biophys. Res. Commun. 96: 1812-1820.

6. Rosenfeld, R., A. V. Thorsson, and R. L. Hintz. 1979. Increased somatomedin receptor sites in newborn circulating mononuclear cells. J. Clin. Endocrinol. Metab. 48: 456-461.

7. Kelly, P. A., B. I. Posner, T. Tsushima, and H. G. Friesen. 1974. Studies of insulin growth hormone and prolactin binding: ontogenesis, effects of sex, and pregnancy. Endocrinology. 95: 532-539.

8. Blazquez, E., B. Rubalcava, R. Montesano, L. Orci, and R. H. Unger. 1976. Development of insulin and glucagon binding and the adenylate cyclase response in liver membranes of the prenatal, postnatal, and adult rat: evidence of glucagon "resistance". Endocrinology. 98: 10141023.

9. Thorsson, A. V., and R. L. Hintz. 1977. Insulin receptors in the newborn. Increase in receptor affinity and number. N. Engl. J. Med. 297: 908-912.

10. Herzberg, V. L., J. M. Boughter, S. K. Carlisle, F. Ahmad, and D. E. Hill. 1980. ${ }^{125}$ I-Insulin receptor binding to cord blood erythrocytes of varying gestational age and comparison with adult values. Pediatr. Res. 14: 4-7.
11. Sara, V. R., K. Hall, and L. Wetterberg. 1981. Fetal brain growth: a proposed model for regulation by embryonic somatomedin. In The Biology of Normal Human Growth. M. Ritzén, A. Aperia, K. Hall, A. Larsson, A. Zetterberg, and R. Zetterström, editors. Raven Press, New York. 241-252.

12. Moses, A. C., S. P. Nissley, P. A. Short, M. M. Rechler, and J. M. Podskalny. 1980. Purification and characterization of multiplication-stimulating activity. Eur. J. Biochem. 103: 387-400.

13. Hall, K., J. Brandt, G. Enberg, and L. Fryklund. 1979. Immunoreactive somatomedin $\mathrm{A}$ in human serum. $J$. Clin. Endocrinol. Metab. 48: 271-278.

14. Bygdeman, M., and N. J. Christensen. Termination of second trimester pregnancy by laminaria and intramuscular injections of 15 methyl $\mathrm{PGF}_{2 \alpha}$ methyl ester or 16-

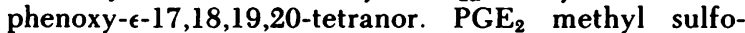
nylamide. A randomized study. Acta Obstet. Gynecol. Scand. In press.

15. Marshall, R. N., L. E. Underwood, S. J. Voina, and J. J. Van Wyk. 1974. Characterization of the insulin and somatomedin receptors in human placental plasma membranes. J. Clin. Endocrinol. Metab. 39: 283-292.

16. Lowry, O., N. Rosebrough, A. Farr, and R. Randall. 1951. Protein measurement with the Folin phenol reagent. J. Biol. Chem. 193: 265-275.

17. Scatchard, G. 1949. The attractions of proteins for small molecules and ions. Ann. N. Y. Acad. Sci. 51: 660-672.

18. Gréen, K., M. Bygdeman, and N. Wiqvist. 1974. Kinetic and metabolic studies of prostaglandin $F_{2 \alpha}$ administered intra-amniotically for induction of abortion. Life Sci. 14: 2285-2297.

19. Gréen, K., E. Granström, M. Bygdeman, and N. Wiqvist. 1976. Kinetic and metabolic studies of 15-methyl-prostaglandin $F_{2 \alpha}$ administered intra-amniotically for induction of abortion. Prostaglandins. 11: 699-711.

20. Rechler, M. M., J. Zapf, S. P. Nissley, E. R. Froesch, A. C. Moses, J. M. Podskalny, E. E. Schilling, and R. E. Humbel. 1980. Interactions of insulin-like growth factors I and II and multiplication-stimulating activity with receptors and serum carrier proteins. Endocrinology. 107: 1451-1459.

21. Marquardt, H., G. J. Todaro, L. E. Henderson, and S. Oroszlan. 1981. Purification and primary structure of a polypeptide with multiplication-stimulating activity from rat liver cell cultures. Homology with human insulinlike growth factor II. J. Biol. Chem. 256: 6859-6865.

22. Nissley, S. P., M. M. Rechler, A. C. Moses, H. J. Eisen, O. Z. Higa, P. A. Short, I. Fennoy, C. B. Bruni, and R. M. White. 1979. Evidence that multiplication-stimulating activity (MSA) purified from the BRL-3A rat liver cell line is found in rat serum and fetal liver organ cultures. In Hormones and Cell Culture. G. H. Sato and R. Ross, editors. Cold Spring Harbour Laboratory Press, Cold Spring Harbour. 6: 79-94.

23. Van Wyk, J. J., M. E. Svoboda, and L. E. Underwood. 1980. Evidence from radioligand assays that somatomedin $\mathrm{C}$ and insulin-like growth factors are similar to each other and different from other somatomedins. $J$. Clin. Endocrinol. Metab. 50: 206-208.

24. Sara, V. R., K. Hall, H. von Holtz, R. Humbel, B. Sjögren, and L. Wetterberg. 1982. Evidence for the presence of specific receptors for insulin-like growth factors 1 (IGF-1) and 2 (IGF-2) and insulin throughout the adult human brain. Neurosci. Lett. 34: 39-44.

25. Kasuga, M., E. van Obberghen, S. P. Nissley, and M. M. 
Rechler. 1981. Demonstration of two subtypes of insulinlike growth factor receptors by affinity cross-linking. $J$. Biol. Chem. 256: 5305-5308.

26. Dobbing, J., and J. Sands. 1973. Quantitative growth and development of human brain. Arch. Dis. Child. 48: 757767.

27. Sara, V. R., K. Hall, C. H. Rodeck, and L. Wetterberg. 1981. Human embryonic somatomedin. Proc. Natl. Acad. Sci. USA. 78: 3175-3179.

28. Bernard, B., B. Preston, P. Beaupre, K. Elliott, and D. Sadava. 1977. Multiple forms of thymidine kinase during human development. Biol. Neonate. 31: 225-228.

29. Widdowson, E. M., D. E. Crabb, and R. D. G. Milner. 1972. Cellular development of some human organs before birth. Arch. Dis. Child. 47: 652-655.

30. Hill, D. E., J. M. Broughter, S. Carlisle, V. L. Herzberg, and T. J. Sziszak. 1980. The role of insulin in fetal growth. In Endocrinology 80. I. A. Cumming, J. W.
Funder, F. A. O. Mendelson, editors. Canberra A.A.S. 471-474.

31. Cardell, B. S. 1953. The infants of diabetic mothers: A morphological study. J. Obstet. Gynecol. Br. Commonw. 60: 834-853.

32. Van Obberghen-Schilling, E. E., M. M. Rechler, J. A. Romanus, A. B. Knight, S. P. Nissley, and R. E. Humbel. 1981. Receptors for insulin-like growth factor I are defective in fibroblasts cultured from a patient with Leprechaunism. J. Clin. Invest. 68: 1356-1365.

33. Kobayashi, M., J. M. Olefsky, J. Elders, M. E. Mako, B. D. Given, H. K. Schedwie, R. H. Fiser, R. L. Hintz, J. A. Horner, and A. H. Rubenstein. 1978. Insulin resistance due to a defect distal to the insulin receptor: demonstration in a patient with Leprechaunism. Proc. Natl. Acad. Sci. USA. 75: 3469-3473.

34. D'Ercole, A. J., L. E. Underwood, J. Groelke, and A. Plet. 1979. Leprechaunism: studies on the relationship among hyperinsulinism, insulin resistance, and growth retardation. J. Clin. Endocrinol. Metab. 48: 495-502. 